\title{
A distinção entre publicidade enganosa e clandestina e os princípios do Código de Defesa do Consumidor
}

\section{Judith Martins-Costa}

Professora do Departamento de Direito Privado e Processual Civil

da Universidade Federal do Rio Grande do Sul.

Professora na Escola Superior de Magistratura

da Associação dos Juízes do RGS-Ajuris e da

Escola do Minstério Público.

\section{SUMÁRIO}

Introdução. I) $O$ dever geral de correção na veiculação da publicidade. a) A substancialização do conteúdo do princípio da veracidade; b) A proibição da publicidade enganosa como concretização do princípio da vulnera bilidade do consumidor; II) Conseqüências da incidência do dever geral de correção em matéria publicitária; c) Distinções conceituais: publicidade enganosa e publicidade clandestina; d) $O$ dever de correção em face do diferentes tipos e modos da publicidade. Conclusão.

\section{Introdução}

Para além das férias e do calor, outro fenômeno se repete com rotineira monotonia nos verões brasileiros: a chamada "guerra" dos cursos pré-vestibulares com vista à captação da futura clientela, os estudantes que, ao final do ano, prestarão concurso vestibular. Mais do que exaltar as vantagens de seus métodos de ensino, a excelência de seus mestres ou a adequação de suas instalações, as escolas e os cursos que preparam ao concurso vestibular para o ingresso na universidade encontram, nos próprios alunos que lograram aprovação no concurso, a mais eficaz arma de combate, a qual se mostra imbatível se, entre os aprovados egressos de tal ou qual escola encontram-se os primeiros colocados no vestibular: o "primeiro colocado", especialmente, tem aí afirmada, através de mensagens publicitárias divulgadas nos jornais e na televisão, a origem de seu sucesso, vale dizer, a escolha, um ano antes realizada, do estabelecimento de ensino que tão bem o preparou para conquistar a vaga universitária.

R. Fac. Direito UFRGS, Porto Alegre, 9(1): 78-88, nov. 1993
As escolas e os cursos pré-vestibulares oferecem serviços de ensino. A qualidade do bem que prestam é sublinhada pela eficiência do serviço prestado. Se é certo que os alunos melhor preparados conquistam as primeiras vagas, para atestar tal eficiência o estudante, primeiro colocado no vestibular, é despersonalizado, transformando-se no bem, ou coisa, signo desta eficiência.

Assim como o "lavar mais branco" é a garantia da eficiência do sabão em pó e da vantagem, para o consumidor, em escolhêlo entre os similares, a boa colocação no vestibular dos alunos egressos de determinado curso é a garantia da eficiência do serviço de ensino prestado. Bem por isto, a divulgação da origem escolar dos vestibulandos bem sucedidos se transmuta em insuperável instrumento de venda do peculiar serviço o ensino - oferecido pelo curso pré-vestibular.

Atentas aos riscos do fenômeno por elas próprias criado para atender, por sua vez, aos seus próprios clientes, as empresas de publicidade sofisticam as técnicas de marke- ting e sutilizam as mensagens veiculadas a ponto de tornar o mais tênue possível limite ético entre a explícita publicidade do serviço que visam a oferecer ao público vale dizer, as excelências da prestação de ensino da escola que é sua cliente - e técnica de reificação do estudante vencedor. As "homenagens" e as "congratulações", veiculadas publicitariamente junto à divułgação dos resultados do vestibular, comprovam suficien- temente a assertiva.

A publicidade é, contudo, uma atividade que, ao contrário da prestação de "homen gens" ou "congratulações", deveres que decorrem das regras sociais de cortesia, objetiva, basicamente "estimular o consumo de bens e serviços" ${ }^{11}$.

Constitui seu escopo "ressaltar as qualidades do produto (ou serviço), persuadi pessoas a comprá-lo e recordar às pessoas que já o adquiriram que o podem fazer d novo"2. Em outras palavras, publicidade é informação difundida ao público "com objetivo de promover, directa ou indirecta mente, uma actividade económica" ${ }^{3}$. Daí resulta, inclusive, o discrime conceitual entre "publicidade e propaganda" ${ }^{4}$ esta afastada, ao menos diretamente, dos fins comerciais, aquela inserida de forma direta e imediata na atividade econômica, de maneira especial no chamado "ciclo do consumo". Por esta razão vem regulada nas normas protetivas aos consumidores, entre nós no Código de Defesa do Consumidor ${ }^{5}$.

O exame destes casos, de certa forma ainda comuns no país que apenas começa a compreender a real extensão da proteção conferida legalmente aos consumidores, poderá talvez ser melhor realizado se se partir de um caso concreto. Adoto, pois, como paradigma, publicidade recentemente veiculada na página 24 da edição de 6 de fevereiro de 1993 do jornal "A Gazeta", de Vitória (ES), na qual um tradicional estabelecimento de ensino daquela cidade, o Colégio Salesiano, a pretexto de homenagear o estudante André Luiz Domingues, seu antigo aluno entre a $5^{\text {a }}$ série do segundo grau e o primeiro ano científico, divulgou, em texto graficamente destacado, o fato de ter o mes- obtido o primeiro lugar no vestibular eral da Universidade Federal do Espírito Santo - graficamente também destacando a sua experiência em "30 anos de vestibular", em texto colocado logo abaixo da indicação de seu nome e logotipo - e inserindo, entre mbos os textos, em letras de pouquíssimo destaque gráfico, a expressão do seu "orgulho" com a vitória do ex-aluno que lá estudara, pelo menos dois anos antes ${ }^{6}$.

Para a adequada análise da publicidade levada a efeito pelo Colégio Salesiano outros dados, também expressos no mesmo jornal, são relevantes. O estudante vitorioso realizara os seus estudos pré-vestibulares em outra escola, o Colégio Darwin, onde estudara na segunda e terceira séries do segundo grau, como informa, à página 15 , reportagem institulada "Primeiro colocado teve 308,5 pontos". No mesmo veículo jornalístico, peça publicitária do próprio Colégio Darwin traz também idêntica informação.

Neste quadro será interessante saber se a publicidade procedida pelo Colégio Salesiano encontra ou não limites ou vedação na tutela conferida aos consumidores pela Lei $8.078 / 90$. Para responder a esta indagação, mister que se compreenda previamente o significado do dever geral de correção na veiculação da publicidade, estabelecendo-se as áreas de interface entre tal dever e os princípios e regras do Código de Defesa do Consumidor (I). Após, será necessário averiguar as conseqüências do dever geral de correção da informação publicitária albergado pela lei, discernindo-se entre as hipóteses de publicidade clandestina e enganosa averiguando-se as formas de sua configuração diante dos diferentes tipos e técnicas publicitárias (II).

I) $O$ dever geral de correção na veiculação da publicidade

A alocação, na Lei $8.088 / 90$, do direito dos consumidores à proteção contra a publicidade enganosa e abusiva (art. $6^{\circ}$ IV) e de seus consectários - o princípio da identificação da mensagem publicitária (art. 36) o da veracidade da mensagem publicitária 
(art. 37, § $1^{\circ}$ ), o da vinculação contratual da mensagem (art. 30), o da não abusividade (art. $37, \S 2^{\circ}$ ), o do onus probandi a cargo do fornecedor (art. 38) e o da correção do desvio publicitário (art. 56, XII) - suscitou esforços interpretativos conducentes à definição de certos pontos de apoio ao preenchimento do seu conceito, uma vez que, sob uma mesma expressão, "publicidade enganosa", visou a lei interditar uma série de práticas faticamente distintas entre si Para compreender a extensão do conceito, caberá, de início, referenciar certos dados relativos ao desenvolvimento do princípio da veracidade (a) e, em perspectiva conexa, a extensão da diretriz inserta no Código de Defesa do Consumidor relativamente ao reconhecimento da vulnerabilidade do consumidor no mercado de consumo (b).

a) A substancialização do conteúdo do princípio da veracidade

O princípio da veracidade da informação publicitária, tido como "o mais importante princípio da actividade publicitária", não tem, embora a sua antiga regulamentação legal, ${ }^{8}$ significado unívoco e absoluto. Em termos amplíssimos, significa a proibição do engano em matéria publicitária, originando-se, conforme anota Carme Madrenas i Boadas em proficiente estudo acerca do direito espanhol e comparado, na disciplina contra a concorrência desleal, por forma a castigar as afirmações falsas no comércio. Desde a sua origem, todavia, as noções de fraude, falsidade e engano, que tradicionalmente o embasam, vêm sendo objeto de diferentes leituras, não só porque são relativas historicamente, como também porque são relativizadas, segundo o objeto da proteção que ampara a proibição".

Em razão desta relatividade, ínsita, de resto, a qualquer conceito e instituto jurídico, a compreensão e a aplicação do princípio de veracidade, ou de respeito à verdade, fulcro da disciplina legal repressiva ao engano em matéria publicitária, atravessou diversas fases, paralelas à própria evolução do comércio e ao perfil econômico da socieda80 de: desde um entendimento formal, correspondente ao período da exclusiva proteção aos comerciantes (quando, no amadurecimento da economia liberal, o sistema passa da livre concorrência ao monopólio), após ultrapassando a época em que se mostrou necessário compor juridicamente os interesses empresariais na defesa de sua "clientela" (compatibilizando os princípios opostos da proteção ao crédito e da veracidade ${ }^{10}$ ), para chegar-se à fase que se poderia denominar de "autonomização da clientela" e sua transformação (que não se limita ao nível semântico) em "consumidores". A partir daí - os interesses destes adquirido efetivo peso no ciclo econômico e aberto o caminho da legitimação processual dos consumidores $e$ do reconhecimento da responsabilidade contratual e extracontratual do anunciante - a compreensão do princípio da veracidade se substancializa, passando a adquirir a função de forma de controle das condutas no mercado ${ }^{11}$, fundada no dever geral de correção das condutas no mercado de consumo, o qual, entre nós, encontra-se positivamente estatuído no art. 4, III, do Código de Defesa do Consumidor ${ }^{12}$.

Em conseqüência, o conteúdo do ilícito publicitário fundado no engano igualmente se transforma. Quando a publicidade dos produtos e serviços postos no mercado "deixa de ser uma arma competitiva rudimentar e com a evolução econômica e o desenvolvimento dos meios de comunicação de massas estende paralelamente seus tentáculos e se adapta aos novos meios, o conteúdo do ilícito publicitário desleal também se irá modificando"13. De um sentido meramente negativo e formal, isto é, "não informar enganosamente", "ater-se à correspondência entre o conteúdo da mensagem e as características do produto ou serviço", evolui-se para uma concepção positiva e substancial vale dizer, "informar correta e completamente", "atentar para que a correspondência entre a mensagem e as características do produto não se desvie pela utilização de palavras ou imagens que possam induzir em equívoco, mesmo se este decorra da ambiguidade na sua utilização". Modificam-se, por igual, para se alargar, os limites da intervenção estatal na matéria, colocando-se aos intérpretes e aplicadores a difícil tarefa da concreção ${ }^{14}$ do princípio.

b) A proibição da publicidade enganosa como concretização do princípio da vulnerabilidade do consumidor

Atualmente, a intervenção estatal em matéria publicitária é balizada, como se viu, por um diverso preenchimento conceitual do princípio da veracidade e seus consectários, vinculando-se à busca do seu significado substancial nos casos concretos. Sobrepaira, contudo, à estatuição concreta de seu conceito, a diretriz fundamental do reconhecimento da vulnerabilidade do consumidor no mercado de consumo (Lei $\mathrm{n}^{\circ}$ $8.078 / 90$, art. $\left.4^{\circ}, \mathrm{I}\right)$.

Para bem compreender a sua extensão, desde logo é importante distingui-lo de outro conceito também inserto no Código de Defesa do Consumidor, com o qual por vezes é equivocadamente confundido: "vulnerabilidade" - não significa o mesmo que "hipossuficiência" (art. 6ㅇ, VIII). Um e outro conceito denotam realidades jurídicas distintas, com conseqüências jurídicas também distintas.

Nem todo o consumidor é hipossuficiênte. O preenchimento valorativo da hipossuficiência - a qual se pode medir por graus se há de se fazer, nos casos concretos, pelo juiz, com base nas "regras ordinárias de experiência"; em seu suporte fático encontrase, em regra, elemento de natureza sócioeconômica. A expressão contida no inciso VIII do art. $6^{\circ}$ constitui o que certa doutrina chama de "conceito juridicamente indeterminado"15 . Sua aplicação depende da discricionariedade judicial e a sua conseqüência jurídica imediata é a da inversão do onus probandi, no processo civil, para a facilitação da defesa daquele tipo por hipossuficiente.

Todo consumidor, seja considerado hipossuficiente ou não, é, ao contrário, vulnerável no mercado de consumo. Aqui não há valoração do "grau" de vulnerabilidade individual porque a lei presume que, neste mercado, qualquer consumidor, seja ele hiper ou hipossuficiente do ponto de vista sócio-econômico, é vulnerável tecnicamente: no seu suporte fático está o desequilíbrio técnico entre o consumidor e o fabricante no que diz com a informação veiculada sobre o produto ou serviço.

Isto porque, por mais poderio econômico que tenha um consumidor individualmente considerado, presume-se que o fornecedor detenha, sobre o bem, determinadas informações cuja ciência constitui seu dever, não o sendo do consumidor. Por esta razão ele é vulnerável à informação e ao instrumento através do qual aquela lhe é em regra fornecida, isto é, a publicidade.

Demais disto, o princípio da vulnerabilidade não se aloca como um "conceito indeterminado", mas como uma diretriz da Política Nacional das Relações de Consumo (art. $4^{\circ}$, caput), de modo que a sua consideração pelo intérprete na análise de qualquer disposição do Código não depende de discricionariedade, mas é vinculativa, porque está o mesmo vinculado às finalidades postas na lei como diretrizes da política nacional para o setor ${ }^{16}$.

Por estas razões o princípio da vulnerabilidade incide no exame de todas as normas do Código, articulando-as entre si. Aplica-se, em especial, àquelas normas que informam o seu sistema da publicidade, conduzindo, bem assim, à prơibição da publicidade clandestina.

II) Conseqüências do dever geral de correção na veiculação da publicidade

Já se anotou que a publicidade constitui um momento fundamental nas práticas comerciais, inserindo-se como a mais relevante das fases componentes do processo de marketing ${ }^{17}$.

Constitui, pois, ação ou conjunto de ações de imensas repercussões econômicas. Análises recentes têm demonstrado a extensão dos custos econômicos da publicidade excessiva ou mal dirigida. Modalidades publicitárias diversificam-se, objetivando diminuir custos econômicos e sociais e atingir, 
com eficácia, o "público-alvo". Em certas ocasiões, busca-se vender diretamente certo produto ou serviço; em outras, é objeto da peça publicitária, a própria imagem da instituição ou empresa. Técnicas diversas se multiplicam. Em certos casos as peças publicitárias tentam dissimular a sua natureza, sempre em busca da melhor relação custobenefício na persuasão dos potenciais consumidores.

A diversa tipologia da mensagem publicitária acarretará, conforme o caso, enfoques também diversos no que concerne à aplicáąão da tutela posta no Código de Defesa do Consumidor. Será preciso anotar inicialmente os conceitos de publicidade veraz e de suas antinomias, a publicidade clandestina e enganosa - confrontando-os a seguir com os diferentes tipos de mensagem publicitária.

\section{c) Distinções conceituais: publicidade} clandestina e enganosa

Como é sabido, distingue-se tecnicamente a publicidade clandestina da enganosa. A primeira tem o caráter oculto, dissimulado, fingindo não ser publicidade o que em realidade é. Disfarça-se, por vezes, em reportagem jornalística. Em outras, em "mensagens de apoio", ou em homenagens, as quais tem por fito, basicamente, colocar em evidência o nome do anunciante, seu produto ou serviço, dissolvendo o intuito real de exaltação de suas vantagens ou características - com finalidade de "vender certa imagem" ao público - no escopo aparente da graciosidade da peça.

Há evidente analogia entre as hipóteses de publicidade clandestina, na esfera do direito privado, e de publicidade ou propaganda ilícita, no campo do direito público. No direito administrativo-constitucional é vedada expressamente a publicidade com caráter de promoção pessoal de agentes públicos, a qual é, muitas vezes, levada a efeito através de "mensagens de apoio" feitas na imprensa a determinado governante ou partido político, ou, ainda, através de "mensagens de congratulações", publicadas na im82 prensa (e pagas com o dinheiro público) penas para saudar eventos ou atos de autoridades.

Aí, ausente o caráter "educativo, informativo ou de orientação", tido pela Constituição Federal como pressuposto de licitude destas peças (art. 37, $\S 1^{\circ}$ ), e inserido o nome, a imagem ou o símbolo da autoridade pública que o patrocinou, também se verificam os traços caracterizadores da clandestinidade. Nestes casos, travestida em homenagem ou na eufemística "prestação de contas à comunidade", está, clandestina, a promoção pessoal de autoridade ou servidor público, a qual o leitor atento acaba por perceber. A prática ilegal, conquanto lamentavelmente não infrequente, tem vedação que decorrentes diretamente da incidência de norma constitucional ${ }^{18}$.

Por sua vez, na esfera das relações de consumo é caracterizada como publicidade clandestina, oculta ou dissimulada toda aquela cujo caráter comercial "pode ser, com algum esforço, percebido pelo destinatário, embora a mensagem omita, deliberadamente, seu intuito publicitário"19.

Ocorre que toda a publicidade clandestina é, em certa medida, também enganosa, porque finge ser o que não é: esconde o caráter publicitário que efetivamente tem sob a aparente graciosidade da imagem ou texto veiculado. Nesta perspectiva a enganosidade não será diretamente antinômica ao princípio da veracidade, mas se contraporá ao princípio da identificação da mensagem publicitária, pelo qual se exige, para a configuração da licitude da peça publicitária, que o consumidor a identifique imediata facilmente como tal (art. 36).

Com efeito, embora haja uma clara distinção técnica entre a clandestinidade e a enganosidade da publicidade, ambas visam, por meios diversos, a enganar o consumidor $^{20}$, a primeira através da própria dissimulação do caráter ou natureza da mensagem publicada, a segunda, contrariamente, assumida como peça publicitária que é, mas falseando ou omitindo, em caráter integral ou parcial, informação sobre o bem anunciado. Demais disto, como bem anota An- tonio Herman de Vasconcelos e Benjamin o conceito de enganosidade, passível de ser deduzido do Código, é extremamente amplo, não se reduzindo ao de publicidade falsa uma vez que até mesmo uma publicidade correta pode ser enganosa," seja porque in formação importante foi deixada de fora, seja porque seu esquema é tal que vem a fazer com que o consumidor entenda mal aquilo que se está, realmente, dizendo"121. É expresso o texto legal ao caracterizar a enganosidade não só em razão da falsidade da informação, mas em razão de "qualquer outro modo" hábil à indução do consumidor em erro acerca da "natureza, características, qualidade, quantidade, propriedades, origem, preço e quaisquer outros dados sobre produtos e serviços" (grifei).

O reconhecimento da vulnerabilidade, a relação existente entre esta e a peculia posição do consumidor frente à informação que the é prestada através da publicidade, conduz ao aumento do caráter substancia do princípio da veracidade entendido em sua forma ampla. O Código impõe, ao for necedor, um dever geral de correção, o qua se explicita particularmente - embora não de modo exclusivo - em matéria de veiculação publicitária ${ }^{22}$. Substancialmente, a in formação correta e veraz é aquela que, identificada como tal e não se alocando de forma clandestina nem subliminar, tradu com fidelidade as características, qualidades e vantagens do bem anunciado. Esta definição, por certo genérica, há de ser contrapos ta, todavia, aos tipos e objetivos da publicidade tida, de modo concreto, como objeto de exame.

\section{d) $O$ dever de correção em face dos} diversos tipos e técnicas de publicidade

É por demais conhecida e repetida a afirmação de Baudrillard para quem a arte publicitária "consiste principalmente na invenção de enunciados persuasivos que não sejam nem verdadeiros nem falsos" ${ }^{123}$, de modo que é por esta razão que a mentira clara, induvidosa, escancarada, só raramente contaminará a peça publicitária. Situan- do-se no limite entre o que não é nem inteiramente verdadeiro nem completamente falso (e por isso originando tão variados problemas de natureza ético-jurídica), a publicidade, a par de explorar a técnica da sugestão, da sutileza e da ambigüidade ou do que não é nem inteiramente veraz, nem inteiramente falso, divide-se em dois gran des tipos ou modalidades.

Segundo Antonio Herman de Vasconcelos e Benjamin, comentarista do Código e um dos autores do Anteprojeto, a publicidade pode ser institucional ou promocional, conforme o critério da classificação segundo o seu objetivo. No primeiro caso "o que se anuncia é a própria empresa, não um produto seu"24. A técnica utilizada visa a alcançar objetivos não imediatos, mas que se colocam à promotora do anúncio numa perspectiva de longo prazo:" Em certas ocasiões, especialmente quando a empresa enfrenta problemas de imagem, uma campanha de publicidade institucional pode ser solução para alterar a forma como o público a enxerga", afirma o autor, segundo o qual, nestes casos, inexiste "a preocupação com a venda do produto em si" porquanto a "preocupação é com a marca" 25

Já a publicidade promocional de produto ou serviço tem objetivos imediatos. Não visa "vender" ao público uma boa imagem (traduzida na veiculação de seu nome, marca ou de suas realizações), mas determinado bem, ou determinado grupo de bens. Pode objetivar a introdução de um novo produto no mercado, ou o oferecimento de um novo serviço ou, ainda, objetivar a venda de bem já conhecido em detrimento de outros similares existentes no mercado ${ }^{26}$.

Nem sempre as duas modalidades se apresentam "puras" e absolutamente nítidas em seus traços diferenciadores. A criatividade, decorrência da acirrada competição no mercado, o objeto a ser veiculado, a natureza da prestação oferecida impõem, em certos casos, que se mesclem certos elementos da publicidade institucional e promocional. É a hipótese, por exemplo, de empresa que visa diretamente afirmar o seu nome, $e$, para afirmá-lo, relembra ou sugere serviç 
já prestado, objetivando, com isto, motivar os consumidores para àdquirirem no futuro serviço de idêntica natureza.

Neste tipo "misto" se incluem, justamente, as peças publicitárias de cursos preparatórios ao vestibular, quando divulgam a lista de seus alunos vitoriosos na busca da vaga universitária: ao mesmo tempo que ressaltam a sua imagem, através da afirmação da qualidade de seus serviços de ensino, desejam persuadir os estudantes que deverão se preparar ao vestibular a acorrer, no futuro, àqueles serviços.

Tais tipos ou modalidades de publicida$\mathrm{de}$, a institucional, ou a promocional, ou a mista, são, em princípio, lícitos, desde que por seu intermédio sejam fielmente obedecidos os limites ao engano e as garantias à veracidade e identificação postos no Código de Defesa do Consumidor. Porém, como é intuitivo, diferenciando-se os modelos de publicidade, o aplicador da lei deverá, no momento de concretizar tais princípios garantias, ter em conta essa diversidade de base.

Cuidados que poderiam ser obviados no caso de uma propaganda promocional grosseiramente fraudulenta terão que ser redobrados, se se tratar de uma publicidade institucional ou promocional clandestina e enganiosa.

Deverá ainda o intérprete confrontar o caso concreto com certos elementos mínimos de técnica publicitária para não tolerar enganos postos com sutileza, mas nem por isto menos enganosos. A este respeito refere Carme Madrenas i Boadas caso famoso na jurisprudência inglesa resultante de litígio entre as empresas MacDonald's e Burgerking, ambas fabricantes de hambúrgueres similares e concorrentes, respectivamente o Big Mac e o Whopper, conhecido como o caso do Big Mac, o qual, por certos elementos de contacto com o caso aqui em análise, vale a pena transcrever:

"Para introduzir seu hambúrguer, e considerando, os experts que com o uso do nome Big Mac e sua comparação seria atraí. do um maior número de consumidores do que com a única promoção de suas próprias 84 marcas Whopper e Burgerking, esta (empresa) levou a cabo uma campanha publicitária sob o lema, em tamanho destacado, It's Not Just Bỉg Mac, lendo-se na peça publicitária, em letra menos destacada, que "à diferença de outros hambúrgueres, é 100 por cento puro boi, feito na brasa e não frito, e com uma variedade única de acompanhamentos". A MacDonald's ingressou em juízo contra a Burgerking, com fundamento na doutrina do passing-off ${ }^{27}$, porque o público creria que a Burgerking venderia o Big Mac e acudiria em massa a estes últimos estabelecimentos, e (ainda), por engano malicioso, já que o público poderia deduzir implicitamente que os hambúrgueres da MacDonald's não seriam feitos com pura carne bovina. A decisão embasou a proibição (da publicidade) no primeiro fundamento, desconsiderando-se o segundo. Proibiu com base no primeiro porque, conforme uma pesquisa realizada, dez por cento do público acreditara que a Burgerking vendia o Big Mac. O segundo fundamento não foi considerado, porque foi demonstrado, também através de pesquisas, que a maioria do público não lê a letra pequena e, portanto, não poderia ser enganado, e aqueles que as lessem teriam que se dar conta de que (a expressão) "à diferença" não poderia entender-se como uma alusão direta ao Big Mac. Segundo ainda anota a autora, "um advogado inglês conhecedor destes temas havia previsto um resultado precisamente contrário" 28

Interessa, deste relato, retirar primeiramente os seguintes elementos: a) a publicidade promocional da empresa Burgerking nada falseava diretamente, pois não mentia nem omitia qualidades do produto anunciado; b) utilizou-se a técnica da configuração gráfica do texto através de letras (tipos) grandes e pequenas estes contendo informação verdadeira (a composição do hambúrguer Whopper) e informação que poderia ser dita como desleal à outra empresa (a expressão "à diferença de outros produtos"); c) pesquisa especialmente realizada demonstrou que os consumidores, em sua grande maioria, não lêem informação veiculada através de letras pequenas: d) o texto publi- cado em letras grandes promovia confusão entre o produto vendido pela anunciante aquele comercializado por seu concorrente; e) o elemento desconsiderado pelo juiz dizia respeito a uma vertente, no caso, da doutrina da concorrência desleal, o "engano malicioso", sinônimo de "informação deliberadamente falsa" ou fraude (motivado na expressão "à diferença de outros produtos"), a qual se entendeu não configurada porque os consumidores não costumam ler os textos veiculados em letras pequenas, devendo atinar, se os lessem, que a expressão "à diferença de" não remetia ao hambúrguer Big Mac.

As semelhanças deste caso com a publicidade divulgada pelo Colégio Salesiano residem nos seguintes pontos: a) a publicidade veiculada pelo jornal "A Gazeta" nada falseia diretamente, pois não diz que o aluno se preparou para o vestibular no seu estabelecimento; b) utiliza a técnica da configuração gráfica do texto através da justaposição de textos impressos em tipos grandes e pequenos, estes últimos contendo informação verdadeira (a de que o vestibulando lá estudara da $5^{\text {a }}$ série ao primeiro ano científico); c) a visualização dos textos publicados em letras grandes, vale dizer, a "chamada" "André Luis Domingues, $1^{\circ}$ lugar geral da Ufes" e o "fecho" do anúncio "Salesiano, 30 anos de pré-vestibular * 50 anos de vitória", promove efetiva confusão acerca da verdadeira escola onde o estudante André Luis se preparara para o vestibular, pois é imediato, para o leitor do anúncio, o estabelecimento da relação entre o fato (verdadeiro) de o estudante ter conquistado o primeiro lugar no vestibular e a indicação (errônea) de ter se preparado para a competição estudando no Colégio Salesiano, indicação, esta, sugerida como causa daquele fato. Assim, se não há falsidade decorrente de omissão, o engano é evidente pela sugestão.

As diferenças entre um e outro residem no fato de o anúncio do Salesiano não ter promovido, direta e explicitamente, confusão entre a sua prestação de serviços de ensino e aquelas de atribuição do Colégio Darwin, onde o vestibulando efetivamente estudara no periodo imediatamente antece- dente ao vestibular e, ainda, no fato de não ter incorrido na proibição de engano malicioso, ou fraude, por não ter afirmado, por exemplo, que "à diferença de outras escolas, a sua preparara o candidato classificado em primeiro lugar no vestibular da Ufes". A peça publicitária patrocinada pelo Salesiano foi, de fato, mais sutil do que aquela promovida pelo Burgerking: mais sutil e muito mais ambígua, pois opera, ou induz, com a sugestão criada no leitor em razão da sua configuração gráfica, vale dizer, a mescla de tipos grandes e pequenos, "escondida", nestes, a informação que quebraria a relação (não verdadeira) estabelecida pelos textos grafados em tipos grandes.

Cabe pois averiguar, ao modo de conclusão, se está ou não a ambigüidade desta peça publicitária vedada pelo direito brasileiro, por subsumir-se na hipótese da enganosidade.

\section{Conclusão}

Embora um certo grau de ambigüidade possa ser tido como conatural à publicidade, técnica ou arte, como se viu, da formulação "de enunciados que não são nem inteiramente verdadeiros nem inteiramente falsos", a proteção positivamente assinalada ao consumidor no direito brasileiro impõe limites à ambigüidade, para cuja determinação devem ser considerados a) os motivos da publicidade em causa; b) os seus objetivos, imediatos e mediatos; c) o tipo de publicidade feita; d) a mensagem efetivamente denotada e, e) a pontencialidade de, da ambigüidade existente, decorrer engano.

No caso aqui tomado como paradigma é mais do que lícito supor que o anúncio patrocinado pelo Salesiano não foi gracioso, não se deveu a um mero dever de cortesia: entidades que prestam serviço mediante remuneração, como as escolas privadas, não constumam cumprir com os ditames da cordialidade através de caras peças publicitárias sem esperar, como é natural, um "retorno" ao investimento financeiro feito. A mensagem publicitária em causa, assim, mais do que expressar a homenagem da escola a quem lá estudara anos antes, foi 
motivada pela finalidade de promover a sua imagem, e, por extensão, exaltar a qualidade dos seus serviços de ensino. O tipo publicitário escolhido se situou, portanto, na mescla da publicidade institucional (a promoção da marca, ou nome da escola) e promocional (a promoção da qualidade de seus serviços de ensino). Seguramente, não seria preciso uma superior capacidade intelectual para perceber este fato.

O motivo dessa promoção de sua imagem e da qualidade de seus serviços foi o de captar a futura clientela. Naquele anúncio o Salesiano não estava, de forma direta e imediata, vendendo os seus serviços, mas o estava de forma mediata e indireta. É por todos sabido que o ensino das escola, cujos alunos conquistam os melhores lugares no vestibular é tido e presumido como "o melhor". Se a escola é particular e, portanto, paga, o número de matrículas (e, quiçá, o próprio valor das mensalidades), estimulado pelo fato de a escola ser "a melhor", se reflete no lucro da instituição. Perfaz-se, assim, no caso concreto, o conceito de publicidade, "atividade que visa estimular o consumo de bens e serviços". Tal estímulo não precisa ser direto e imediato e, de fato, nem sempre o é. Assim o atesta a difundida prática do teaser, o anúncio de futuros anúncios, o qual tem por objetivo "criar expectativa ou curiosidade, sobretudo em torno de produtos a serem lançados"29.

O mais grave defeito da publicidade em causa reside, contudo, na mensagem efetivamente denotada. A visualização das mensagens expressas nos dois textos publicados através dos tipos gráficos grandes e sua contraposição à informação transmitida através de tipos pequenos conduz à convicção de que se pretendeu dissimular o que publicidade é com manifestação de cortesia, o que não (apenas) é. A publicidade do Colégio Salesiano se colocou, por isso, no limite da infringência do princípio da identificação da mensagem (art. 36, caput) por promover de imediato a dúvida quanto ao fato de tratar-se de peça publicitária ou homenagem de cortesia. A ambigüidade sobre a natureza da peça, é, aqui, a primeira causa do engano. 86
Apesar disto a mensagem sugere implicitamente, que o sucesso do estudante André Luis na conquista do primeiro lugar se deveu ao fato dele ter se preparado para 0 vestibular: se a maioria dos consumidores não costuma ler o que está grafado em letras pequenas nas peças publicitárias por ter a sua atenção visual atraída para os tipos gráficos maiores, como o demonstrou a aludida pesquisa realizada na Inglaterra - país no qual o nível de escolaridade e cultura da população é sabidamente superior ao nosso no caso examinado mesmo o leitor do anúncio regularmente cauteloso estabeleceria imediatamente a relação entre o primeiro daqueles textos ("André Luis Domingues, 10 lugar geral da Ufes") e o segundo ("Salesiano, 30 anos de pré-vestibular * 50 anos de vitória). A ambigüidade da mensagem é a segunda causa do engano.

Não é demais lembrar, ainda, o contexto onde foi divulgada a peça publicitária em causa, em momento imediato ao anúncio do resultado do vestibular e em veículo que comumente estampa anúncios publicitários de outros cursos e escolas que informam sobre o sucesso, na competição, de estudantes cujos estudos prepararam. Trata-se do contexto onde se desenvolve a já aludida "guerra" das escolas para estabelecer qual a que conquistou o mais expressivo número de "primeiros lugares". O próprio contexto no qual divulgou-se a mensagem atua, portanto, até mesmo do ponto de vista psicológico, como mais um elemento conducente à caracterização do engano.

Por estas razões parece-me incontroverso que a ambigüidade que sustenta tanto a natureza quanto a configuração gráfica $e$ textual da mensagem publicitária em exame são de molde a causar engano, nos termos da hipótese prevista no art. 37, caput e parágrafo $1^{\circ}$ da Lei $8.078 / 90$.

Acresce que a ilicitude do engano publicitário não exige em seu suporte fático a incidência do elemento subjetivo, vale dizer, a intenção de enganar. Como ocorre, em regra, no direito das obrigações, é irrelevante a boa fé subjetiva do anunciante ${ }^{30}$, pois o que se requer é a adstrição à feição objetiva do princípio da boa fé, para o qual pouco importa a caracterização do animus ou do psicologismo do agente: não se perquire se estava o mesmo internamente convicto de agir conforme ao direito; se questiona se, objetivamente, sua conduta se pautou pelos ditames da correção e da lealdade ${ }^{31}$. O mesmo ocorre em relação à má fé. O dolo e a culpa "só ganham destaque no tratamento penal do fenômeno" e, portanto, "sempre que o anúncio for capaz de induzir o consumidor em erro - mesmo que tal não tenha sido querido pelo anunciante - caracterizada está a publicidade enganosa" ${ }^{132}$. De pouco importa saber, pois, se o Colégio Salesiano pretendeu criar a ambigüidade enganosa: o fato relevante para o direito é que objetivamente a criou.

Para a caracterização da ilicitude também não é necessário que a publicidade tenha efetivamente enganado os consumidores. Basta que tenha tido a potencialidade ou a capacidade de anganar. Como bem afirma Antonio Benjamin, em adequada interpretação do Código do Consumidor, "trata-se de juízo in abstracto e não in concreto. $\mathrm{Na}$ caracterização de uma publicidade enganosa o dano do consumidor é um mero plus (com implicações próprias, notadamente na área penal" ${ }^{133}$ ). A razão desta afirmativa encontra-se na expressão utilizada pela lei ("capaz de induzir em erro o consumidor", art. $\left.37, \S 1^{\circ}\right)$, capacidade que "quer dizer 'tendência a induzir em erro'. Por isso mesmo, não é imprescindível o depoimento dos consumidores no sentido de que foram, efetivamente, enganados" ${ }^{134}$.

Como se observa, portanto, é amplíssimo o espectro da proibição ao engano publicitário, contrafacie necessária ao dever de correção da informação publicitária e ao direito dos consumidores a uma informação veraz e substantiva, este dever foi, incontroversamente descumprido através da peça publicitária patrocinada pelo Colégio Salesiano, por forma a atingir o direito reconhecido pela lei aos consumidores a uma informação não enganosa, divulgada através de mensagem clara e imediatamente identificável como tal. E por igual amplo o rol das sanções postas na lei para coibir e punir a infração à proibição do engano como garantia dos interesses que tutela.

Resta saber se, no caso examinado, as competências que a lei prevê foram efetivamente exercidas.

\section{Notas}

1 Conforme expresso no "Código Brasileiro de AutoRegulamentação Publicitária", art. $8^{\circ}$.

2 Segundo Maria Elisabete Vilaça Lopes, O Consumidor e a Publicidade, Revista Direito do Consumidor, vol. 1, p. 151, Editora Revista dos Tribunais, São Pauo, 1992

${ }^{3}$ Carlos Ferreira de Almeida, in Conceito de Publicidade, Boletim do Ministério da Justiça no 349 , Lisboa, 1985, p. 133, grifos meus.

${ }^{4}$ Para esta distinção, além do já citado trabalho de Maria Elisabete Vilaça Lobo, ver, na doutrina brasileiA Antonio Herman de Vasconcelos e Beniamin, Có digo Brasileiro de Defesa do Consumidor Comentado pelos Autores do Aefesa do Consumidor Comentado pelos Aurs do Asteprojeto, Ed. Forense Universitade, Rio de janiro, Alicap 172 ess, ainda, estudo

${ }^{5} \mathrm{O}$ tratamento da publicidade se presta, evidentemente, a uma análise interdisciplinar. Mesmo no interior do Direito pode ser enfrentada desde os mais variados ângulos de exame, v.g. as regras que proibem a concorrência desleal $e$ as leis antitrust. Atualmente, na maioria dos paises, em razão da emergência de leis que disciplinam as relaçōes de consumo, o enfoque tradicional e de onde se originou a sua disciplina jurídica, 0 instituto da concorrência desleal, tem cedido espaço ao enfoque ditado pela proteção aos consumidores, embora não estejam, ambos, de todo afastados. Ver, na matéria, a monografia de Carme Madrenas i Boadas, Sobre la intepretación de las probibiciones de publicidad engañosa y desleal - la parcialidad de la publicidad y los costes de la competencia, Editorial Civitas, Madri, 1990.

6 O texto exato indica, em letras de tipo grande, sobre fundo escuro: André Luis Domingues $1^{\circ}$ lugar geral da Ufes. Segue-se, em letras minúsculas, sobre fundo claro, o texto: O Salesiano se orgulha pela grande vitoria do seu ex-aluno, André, que aqui cursou da $5^{1}$ serrie ao base Aban bo no, igulme, sob o no estos en lipos grandes, a mensatibular * 50 anos de vitória.

7 Assim Carlos Ferreira de Almeida, Os Direitos dos Consumidores, Livraria Almendina, Coimbra, 1982, p. 81

8 Anota Carlos Ferreira de Almeida que sua origem remonta ao tratamento legal da concorrência desleal. por criação jurisprudencial, aparecendo na Alemanha 
em 1890. Sobre a evolução da matéria, Carme Madrenas i Boadas, op. cit., pp. 28 a 42 . No direito brasileiro a concorrência desleal vem tratada no Decreto-Lei 7.903/45, tipificando-se os crimes nos incisos do art. 178, revigorado pelo vigente Codigo de Propriedade Industrial (art. 128). Considera-se crime, entre outros, o de publicar, pela imprensa ou qualquer outro meio falsa afirmaça em detrimento de concorrente com fim de obter vantagem indevida, bem como a divulga ção, sobre o concorrente, de falsa informação capaz de

${ }^{9}$ Carme Madrenas i Boadas, op. cit., pp. 25 e ss.

10 Segundo Carme Madrenas i Boadas "bacia los años 50 la evolución económica fuerza a buscar nuevas formulas en la composición de los intereses empresariales y trata ponerlos al día compatibilizzándolos con los intereses de ponerlos al dia compatibili zandolos con los intereses de los
consumidores. Ello supuso un desplazamiento de la líned fronteriza que separaba la protección del crédito y el principio de veracidad. El cambio repercutió también en la interpretación del principio de veracidad. La exigencia de transparencia en las prestaciones pasa a ser un objectivo urgente Pero, mientras la defesa de los intereses de los consumidores no adquiera sanción legal, se bará corresponder formal y tautologicamente con el interés en la 'transparencia' del mercado, el nuevo eufemismo que facilitará en adelante el consenso sobre los intereses que prevalecen effectivamente. La asimetria en la legitimación activa operará a modo de barrera que frena el manera que el principio de respeto de la verdad se entender manera que el principio de respeto de la verdad se entendera primordialmente en el sentido de remoción de los peligros de
desvio de la clientela" (Op. cit., pp. 33 e 44)

${ }^{11}$ Idem, p. 27.

$12 \mathrm{CDC}$, art. 4\%, III, in fine. A noção de "boa fé" que se deduz do Código não é aquela de matriz subjetiva, aplicável em matéria de direitos reais, onde considerada a intenção do agente, mas a boa fé objetiva, de incidência no campo obrigacional, a qual se identifica com um dever geral de correção na atuação no tráfico jurídico. Como afirma Vera Maria Jacob de Fradera ao comentar o dispositivo legal retro-referido, "a recepcāo, pelo Código de Defesa do Consumidor, da idéia de credo/confiança, é de grande relevância, porquanto, nos sistemas jurídicos latinos, de um modo geral, todo o ordenamento jurídico resulta da lei e a 'revolucão jurídica' faz-se por meio dela. Neste caso, modificaçōes haverão de produzir-se na relação de consumo, eis que um comportamento efetivamente regulado por uma regra de teor ético, é preconizado como presidindo no seu todo, a relaçăo". (A Interpretação da proibicão de publicidade enganosa e abusiva à luz do principio da boa fé: o dever de informar no Código de Defesa do Consumidor, comunicação exposta no III Congresso Internacional do Direito do Consumidor 1992, Canela, RGS e publicada na Revista Direito do Consumidor vol. 4, 1993. Escrevi brevemente sobre a distinção da boa fé objetiva e subjetiva em Crise Modificação da Idéia de Contrato no Direito Brasile ro, Revista Direito do Consumidor, vol, 3 , Säo Pauto Editora Revista dos Tribunais, 1992 p. 127, em especial p. 141
13 Carme Madrenas i Boadas, op. cit., p. 33, traduzi. ${ }^{14}$ Sobre a idéia de "concreção" ver Larenz, Metodologia da Ciência do Direito", tradução de J. de Sosa Brito, p. 15 Ver Karl Engish, Introdução à Ciência do Direito, Editora Fundação Calouste Gulbenkian, Lisboa, $1^{\mathfrak{a} e d i-}$ ção, pp.

Sobre a matéria, remeto à conferência apresentada por Eros Roberto Grau no III Congresso Brasileiro de Direito do Consumidor, Canela, RS, março de 1992, a qual comentei em estudos publicados na Revista Direito do Consumidor, vols. 4 e 5.

17 Para estas noções, ver os já citados estudos de Antonio H. V. e Benjamin, pp. 138 e ss, e Maria Elisabete Vilaça Lopes, p. 150

${ }^{18}$ Examinei a vedação a tais práticas em estudo publicado na Revista de Direito Público, vol. 97, p. 166 Evidentemente, ai se trata de "propaganda", e não de "publicidade", muito embora não tenha a Constituição seguido a distinção conceitual entre os dois termos.

${ }^{19}$ Maria Elisabete Vilaça Lopes, op. cit, p. 154, grifei 20 No mesmo sentido Antonio H. V. Benjamin, op cit., p. 186, como segue: "Publicidade que não quer assumir a sua qualidade é atividade que, de uma form ou de outra, tenta enganar o consumidor. $\mathrm{E} o$ engano, mesmo o inocente, é repudiado pelo Código de Defes do Consumidor".

21 Op. cit, p. 194, grifei.

22 Como já assinalei acima tal dever decorre da adstrição ao princípio da boa fé objetiva (art. $4^{\circ}$, III, in fine conjugado, para o que aqui concerne, com várias outras normas, tais como as do art. $6^{\circ}$, III e IV, o art. $8^{\circ}$ caput, art. $9^{\circ} \mathrm{e}$ art. 20 , caput, além daquelas referentes de modo específico à publicidade (arts. 30,36 a 38).

${ }^{23}$ In A Sociedade de Consumo, tradução de Arthur Morão, Ediçōes 70, Lisboa, 1981, p. 155

24 Op. cit. p. 174

25 Idem, ibidem, grifei.

${ }^{26}$ Para estas referências, Antonio H. V. Benjamin, op cit., pp. 174 e 175.

${ }^{27}$ Por esta expressão se designa, no direito da commo law, o caso de confusão deliberada entre os produto de um anunciante e os de seu competidor.

28. Op. cit., pp. 22 e 24, nota 1, traduzi. A fonte referida é Jeremy Philips, Passing off and trade libel: the "Big Mac case", J. Bus.L., 1986, pp. 240 a 242.

${ }^{29}$ Código Brasileiro de Auto-regulamentação publicitária, art. $9^{\circ}$.

${ }^{30}$ Assim Antonio H. V. Benjamin, op. cit. p. 195

1 Ver Mario Júlio de Almeida Costa, Direito das Obrigações, 5a edição, Almendina, Coimbra, 1991.

32 Antonio H.V. e Benjamin, idem, ibidem.

33 Idem, p. 197.

34 Idem, ibidem.

\section{Ética notarial}

Antônio Carlos Falcão Dornelles

Professor Assistente da Faculdade de Direito de Porto Alegre, onde prelecionou:

Filosofia de Direito, como assistente do Prof. Armando Câmara;

Direito Administrativo, como assistente do Prof. Paulo Pasqualini;

Prática Extra Forense, disciplina pela qual é atualmente responsável;

Vinculado ao Departamento de Direito Público e Filosofia do Direito;

Tabelião titular do Terceiro Tabelionato de Porto Alegre.

1. Como profissional do direito tem o notário sua ação norteada pela idéia do bem comum. Esta afirmativa resulta, é bem de ver, de uma investigação em torno dos conceitos do direito, da justiça, (sem a qual aquele não se formula) e do fim a que ambos se dirigem: o bem comum.

Não vamos, evidentemente, porque seria incabível nos limites deste trabalho, desenvolver todos os passos daquela investigação, mas podemos, sucintamente, apresentarlhes os resultados e, conseqüentemente, base da afirmativa que abre este trabalho.

Que é direito? Que é justiça? Que é bem comum?

Seguindo os passos do Prof. Armando Câmara, da Faculdade de Direito de Porto Alegre, cujos conceitos endossamos inteiramente, podemos formular os aludidos conceitos da seguinte forma: direito é um conjunto de princípios práticos, radicados na natureza racional e social do homem, descobertos pela razão, e destinados a regular as relações inter pessoais, em conformidade com a justiça. Justiça, por sua vez, é a conformidade de uma relação inter pessoal com o bem comum, vindo este a ser o conjunto das situações pessoais e sociais de vida que asseguram a realização dos fins totais do homem.

Justiça e direito, ambos, têm como fim o bem comum. O direito realiza-o diretamente; a justiça, indiretamente, através do direito.

Imbrica-se, a função notarial, a toda evidência, dentre aquelas situações sociais necessárias à realização do bem comum, do que é prova a universalidade da instituição notarial, encontrada dentro da organização urídica dos mais variados países, independentemente de sua ideologia política e de sua estrutura social e econômica.

Cabe, assim, indiscutivelmente, ao tabelião, uma parcela da responsabilidade social na realização do bem comum, homem do direito que é, como se disse linhas acima. Ora, "inverificável é o divórcio entre direito moral porque a moralidade não é uma virtude meramente subjetiva e, como tal, de projeção discutível na vida do homem como ser gregário, e nos destinos visíveis das sociedades. Ao invés, moralidade vale por aperfeiçoamento gradativo da espécie humana, por inclinação para a perfectibilidade da solidariedade social, e para a afirmação cada vez mais completa da justiça entre os homens. "(Queiróz Lima: "Princípios de Sociologia Jurídica, in "Introdução ao Estudo do Direito" de Roberto Piragibe da Fonseca)

2. Dentro da função notarial coexistem atividades diferenciadas, visto ser, a mesma, complexa, ao menos entre os povos que adotam a organização latina do notariado. Assim, o tabelião: a) - é consultor de seus clientes, a quem assessora e aconselha; ("Cumpre aos tabeliães indagar da identidade e capacidade das partes, e instruí-las sobre a natureza e conseqüências do ato que pretendem realizar" - Código de Organização Judiciária do Estado do Rio Grande do Sul, artigo 339). b) - preside seus atos jurídicos, realizando a política jurídica destes c) - reveste estes mesmos atos de forma instrumental adequada; d) - conserva os origi-

R. Fac. Direito UFRGS, Porto Alegre, 9(1): 89-93, nov. 1993 